\title{
Identification and Characterization of Resistance to Phytophthora infestans in Leaves, Stems, Flowers, and Tubers of Potato Clones in the Pacific Northwest
}

\author{
L. D. Porter, Department of Plant, Soil and Entomological Sciences, University of Idaho, Aberdeen Research and \\ Extension Center, Aberdeen 83210-0870; D. A. Inglis, Washington State University-Mount Vernon Research and \\ Extension Unit, Mount Vernon 98273-4768; and D. A. Johnson, Department of Plant Pathology, Washington State \\ University, Pullman 99164-6430
}

\begin{abstract}
Porter, L. D., Inglis, D. A., and Johnson, D. A. 2004. Identification and characterization of resistance to Phytophthora infestans in leaves, stems, flowers, and tubers of potato clones in the Pacific Northwest. Plant Dis. 88:965-972.

Resistance to Phytophthora infestans in leaves, stems, flowers, and tubers of eight cultivars grown commercially in the Columbia Basin and 29 advanced clones from the Tri-State Potato Variety Development Program was quantified. Foliage of all eight cultivars was susceptible in field and greenhouse tests. Six advanced clones had high levels of resistance in stems and leaves in the field at Mount Vernon, WA, but only two of these six clones had high levels of resistance in leaves and stems in greenhouse tests. Flowers of most plants with high to moderate levels of foliar resistance were susceptible to infection in both the field and greenhouse. Tubers of Umatilla Russet, Russet Legend, Gem Russet, and nine advanced clones, including A90586-11, had high levels of resistance in most laboratory tests. Level of foliar resistance against US-8 and US11 clonal lineages of $P$. infestans was variable among clones, but tuber resistance by pathogen clonal lineage varied little among clones. Clones with high resistance expressed quantitative differences compared with susceptible cultivars and likely possess a high level of partial resistance.
\end{abstract}

Additional keywords: screening, Solanum tuberosum

Late blight, caused by Phytophthora infestans (Mont.) de Bary, is one of the most damaging diseases of potato worldwide (9). Yield losses in the field occur when tubers become infected during the growing season or at harvest. Losses in storage due to tuber rot were estimated at $\$ 3.0$ million in 1995 and $\$ 1.4$ million in 1998 in the Columbia Basin of Washington and Oregon $(20,21)$.

Currently in the Columbia Basin of Washington, cvs. Shepody, Umatilla Russet, Russet Norkotah, Ranger Russet, and Russet Burbank make up 7, 12, 19, 20, and $35 \%$, respectively, of the potato production area (19). Unfortunately, foliage of all these cultivars is susceptible to $P$. infestans $(15,16)$, and tubers of only Umatilla Russet are resistant to the pathogen (31).

Corresponding author: L. D. Porter

E-mail: ldporter@uidaho.edu

Funding was provided by the Washington State Potato Commission. Plant Pathology Number Series 0374, Department of Plant Pathology, College of Agriculture and Home Economics Research Center, Project 0678, Washington State University, Pullman.

Accepted for publication 22 April 2004.

Publication no. D-2004-0621-02R

(C) 2004 The American Phytopathological Society
Disease-resistant cultivars are an effective and economical means to manage plant pathogens $(2,34)$ which has been explored as a way to manage late blight since the 1840s (41). Oregon, Idaho, and Washington formed the Tri-State Potato Variety Development Program (TSPVDP) in 1984 to insure cooperative efforts in the development of potato cultivars with desirable horticultural characteristics and resistance to potato pathogens, including $P$. infestans. Resistance in potato to $P$. infestans has been classified as immunity (30), general or durable (12), partial $(3,14)$, and specific $(11,37)$. Immunity implies no sign of the pathogen or symptom of disease on a potential host (22). General or durable resistance is effective against all races of a pathogen and remains effective during prolonged use over a widespread area in an environment conducive for disease development (23). Partial resistance reduces the development or growth of the pathogen (38). Specific resistance is expressed by qualitative differences when genotypes of the host react differentially to genotypes of the pathogen $(8,22)$. Unlike partial resistance, specific resistance is not durable in potato against late blight $(1,29,36)$.

Reduced infection frequency $(7,26)$, reduced lesion expansion $(13,39)$, increased length of latent period $(7,28)$, and reduced sporangia production $(39,40)$ are some of the components of partial resistance that have been measured previously. The susceptibility of flowers, particularly among partially resistant potato clones, has not been measured. Presence of susceptible flowers could coincide with spore showers and affect timing of fungicide applications or require breeding for flowerless clones.

The purpose of this study was to identify and characterize resistance to $P$. infestans in foliage (leaves and stems), flowers, and tubers of some of the advanced clones in the TSPVDP that might be suitable for potato production in the Pacific Northwest of the United States, and to compare the resistance of these clones to commercial cultivars currently grown in the Columbia Basin region. Knowing the relative resistance in various plant organs of clones in the TSPVDP would be valuable in selecting for complete plant resistance.

\section{MATERIALS AND METHODS}

Germ plasm. Commercial cultivars and clones from the TSPVDP were evaluated. The TSPVDP has used Solanum tuberosum, the species commonly used in potato production, and crossed it with $S$. bulbocastanum, $S$. demissum, and $S$. stoloniferum, as well as with germ plasm from Poland, the Max Plank Institute in Germany, and the International Potato Center in Peru. Selected advanced clones were tested for foliar and tuber reactions to $P$. infestans in the greenhouse and field during 1998 to 2001. Seed tubers of plant material used in this study were increased in the field in Tetonia, ID, during the 1998 to 2001 growing seasons. The seed was harvested and sent to Pullman and Mount Vernon, WA, and stored at $4^{\circ} \mathrm{C}$ until use.

Greenhouse plant preparations. Seed tubers of clones for greenhouse experiments were removed from cold storage and warmed until eyes began to sprout. Eyes were removed from tubers to propagate plants by using a sterile, dish-shaped melon scoop, $2 \mathrm{~cm}$ in diameter, which formed spherical tuber pieces weighing approximately $13 \mathrm{~g}$. Each tuber piece was planted in soil at a depth of $5 \mathrm{~cm}$ in $15-\mathrm{cm}-$ diameter plastic pots containing Garden Rite potting soil (3:1:1, vol/vol/vol, peat moss:pumice:sand; Soil Conditioners, Zillah, WA]. A preplant fertilizer of $1.10 \mathrm{~g}$ of Agriliance Lawn and Garden Food 
(Agriliance Agronomy Co., St. Paul, MN) containing 16:16:16 N-P-K was incorporated into the potting soil. Plants were fertilized with $700 \mathrm{ml}$ of Miracle-Gro (Scotts Miracle-Gro Products, Inc., Marysville, $\mathrm{OH}$ ) containing 15:30:15 N-P-K at a concentration of $4 \mathrm{~g}$ per 3.78 liters every 2 weeks after emergence.

Isolates and inoculum. Isolates 1799, 701, and 110B of P. infestans were used in these studies. Isolates 1799 and 701 were collected from potato foliage from central Washington in 1999 and 2001, respectively, and were of the US-8 clonal lineage (10). Isolate $110 \mathrm{~B}$ was isolated from potato foliage collected in western Washington in 1997 and was of the US-11 clonal lineage (10). Isolates were maintained and increased on excised leaflets of cv. Ranger Russet or Russet Burbank.

Inoculum was increased on detached leaflets placed on a fiberglass screen over moistened paper towels in sealed plastic containers and incubated at $15^{\circ} \mathrm{C}$ with an 18-h photoperiod. Sporangia were washed from sporulating lesions on the leaflets, and the sporangial suspension was adjusted to $1 \times 10^{4}$ sporangia/ml using a hemacytometer and chilled at $4^{\circ} \mathrm{C}$ for $2 \mathrm{~h}$ before inoculation. Plant tissues were inoculated by placing $50 \mu \mathrm{l}$ of the suspension on a $1-\mathrm{cm}^{2}$ piece of filter paper and applying the square to the potato tissue. Inoculated plants were placed in mist chambers for $18 \mathrm{~h}$ with a range in mean temperature between 15 and $26^{\circ} \mathrm{C}$ across all experiments. Following the mist cycle, mist chambers were turned off and foliage or tubers were allowed to dry for $24 \mathrm{~h}$ with a range of mean temperature between 16 and $29^{\circ} \mathrm{C}$ across all experiments. All experiments were repeated.

Greenhouse foliage and flower experiments. Foliage and flowers of cultivars and advanced clones were evaluated for resistance to $P$. infestans in four experiments from 1999 to 2000. Plants were inoculated during early tuber bulking in all tests (32). A single stem was allowed to develop for each whole plant. Three to five leaflets, one or two stem locations, and none to two flowers were inoculated on each plant, depending on the experiment. Inoculated leaflets ranged from the top to the bottom of the stem. When only a single inoculation per leaf was performed, leaflets were inoculated on the right proximal leaflet adjacent to the terminal leaflet facing out from the stem. When two inoculations were performed per leaf, both the right and left leaflet adjacent to the terminal leaflet were inoculated on each leaf. When there was a single inoculation site, the stem was inoculated at the midpoint of its length between two internodes, and at the midpoint and $2.5 \mathrm{~cm}$ below the midpoint on opposite sides from each other if there were two stem inoculation sites. Young flowers that had not opened or were just beginning to open were inoculated on the stigma. The filter paper used to inoculate flowers was $0.5 \mathrm{~cm}^{2}$. If all the plants for an experiment fit in a single mist chamber (experiments 1 and 2), plants were arranged in a completely randomized design in a single mist chamber. Otherwise, plants were arranged in a randomized complete block with the block being the mist chambers (experiments 3 and 4). Three or four replicates were used in each experiment. Whole plants were placed in a mist chamber for $18 \mathrm{~h}$ followed by a $24-\mathrm{h}$ dry period, and then placed in a greenhouse. Mean temperature in the greenhouse ranged from 16 to $23^{\circ} \mathrm{C}$ during the day and from 16 to $18^{\circ} \mathrm{C}$ at night.

Inoculated leaflets, stems, and flowers were monitored daily for lesion formation. Measurements for lesion size began when symptoms were first observed, which generally was $60 \mathrm{~h}$ after inoculation for leaflets and stems and $104 \mathrm{~h}$ for flowers. Measurements for lesion size on flowers began when symptoms were first observed on the pedicle of the flower after hyphae of $P$. infestans had moved through the pistil of the flower from the stigma inoculation site. Lesion expansion down the pedicle then was measured. Size of lesion on leaflets, stems, and flower pedicles was measured every $12 \mathrm{~h}$. Leaflet lesion area was calculated by arranging the lesion visually into a rectangle and calculating the area (length by width). Lesions on leaflets and stems were measured until lesions on the most susceptible clones reached the outer edge of the leaflet blade, which took place between 112 to $178 \mathrm{~h}$ after inoculation. Stem and flower lesion area was calculated by measuring the width and length of the lesion down one half of the stem or pedicle, respectively. Flower lesions were measured up to $384 \mathrm{~h}$ after inoculation. The area under the lesion expansion curve (AULEC) was calculated for each leaflet, stem, and flower by adapting the equation used to calculate the area under the disease progress curve (33):

$$
\text { AULEC }=\sum_{i=1}^{n}\left[\frac{\left(y_{i}+y_{i+1}\right)}{2}\right]\left(t_{i+1}-t_{i}\right)
$$

where $y_{i}$ is the lesion area $\left(\mathrm{mm}^{2}\right)$ on a leaflet or stem at time $t_{i}$, in hours, and $y_{i+1}$ is the lesion area $\left(\mathrm{mm}^{2}\right)$ on a leaflet or stem at time $t_{i+1}$. AULEC values were used to determine partial resistance (18).

In the first experiment, leaflet and stem lesion size and amount of sporulation on infected leaflets when potato tissue was inoculated with isolate 1799 was determined for eight cultivars and clone A90586-11 in the greenhouse in 1999. Five leaflets and a single stem were inoculated on each plant. Plants were removed from the mist chamber and lesion size was measured on the plants until leaflet lesions reached 1 to $2 \mathrm{~cm}$ in diameter, which took place approximately 5 days after inoculation. Plants again were placed in the mist chambers for $18 \mathrm{~h}$ to induce sporulation on infected leaflets. After sporulation occurred, 12-mm-diameter sections of tissue with sporangia from three of the five inoculated leaflets were removed with a cork borer. Leaves selected were positioned at the top, middle, and bottom on the stem. The cork borer was placed over the tissue to be excised so that half of the bore diameter extended into healthy-appearing tissue and the other half extended into the lesion. The section then was placed into a $130-\mathrm{ml}$ vial with $10 \mathrm{ml}$ of a fixative solution (90:5:5, vol/vol/vol, 95\% ethanol, glacial acetic acid, $37 \%$ formalin). One to three excised sections were taken per leaflet depending on the size of the lesion. The vials were shaken to dislodge sporangia, after which spores in three subsamples per vile were counted with a hemacytometer.

In the second experiment, lesion size on leaflets and stems was determined for eight cultivars and clone A90586-11 in the greenhouse in 2000. Plants were inoculated on three leaves and at two stem locations. Two leaflets were inoculated per leaf with either isolate 701 or isolate 110B. Stems were inoculated at two sites, one site with isolate 701 and the other site with isolate 110B.

In the third experiment, leaflets and stems of 29 advanced clones and two cultivars, Russet Norkotah and Ranger Russet, were evaluated for resistance to $P$. infestans in two trials in the greenhouse in 2000. Plants were inoculated with isolate 1799 in the first trial and with isolate 110B in a second trial. Plants were inoculated on three leaves and at one stem location. In the fourth experiment, leaflets, stems, and flowers of 10 advanced clones and two cultivars, Russet Burbank and Ranger Russet, were assessed for resistance to $P$. infestans in the greenhouse in 2001. These clones were selected because they had foliar resistance to $P$. infestans in the field and greenhouse in 2000. Plants were inoculated at flowering on three leaves and at one stem location. Two leaflets were inoculated per leaf with either isolate 701 or isolate 110B. Two stem locations and two flowers were inoculated on each plant, one with isolate 701 and one with isolate 110B.

Laboratory tuber experiments. Tubers of cultivars and potato clones were evaluated for resistance to $P$. infestans in four experiments from 1998 to 2001. Individual tubers were the experimental unit in all four experiments. Tubers were lightly misted with distilled water and inoculated on a single eye located in the middle of the tuber. When the number of tubers for the experiment fit within a single mist chamber (experiments 1 and 2), the tubers were arranged in a completely randomized design in a single mist chamber. Otherwise, tubers were arranged in a randomized complete block with the block being the mist chambers (experiments 3 and 4). Four to six replicates were used in each experiment. Tubers were placed in a mist cham- 
ber for $18 \mathrm{~h}$ followed by a 24-h dry period. Tubers were placed in storage at $9^{\circ} \mathrm{C}$ after drying and assessed for severity of late blight symptoms after 36 days. Tubers were peeled to an approximate depth of 3 $\mathrm{mm}$ and the percentage of external surface area with late blight symptoms was visually estimated. Commercial cultivars were tested with isolates 1799 and 110B in the first and second tuber experiments, respectively. The advanced clone, A90586-11, was grouped with the commercial cultivars because of its potential for release as a new cultivar, now called 'Defender'. In the third and fourth tuber experiments, advanced clones were tested with both US- 8 and US-11 isolates for resistance. Russet Norkotah, Ranger Russet, and Russet Burbank were used as susceptible standards. The tubers for all tests with a randomized complete block design were also blocked in storage and during the measurements of external tuber rot.

Field trials. Entries were planted 2 June 2000 and 22 May 2001 in a Puget silt loam soil at the Washington State University Research Extension Unit in Mount Vernon, WA. Number of entries was 19 in 2000 and 12 in 2001. Bannock Russet, Gem Russet, Ranger Russet, Russet Burbank, Russet Legend, Russet Norkotah, Shepody, and Umatilla Russet were used as susceptible foliar standards in 2000, and Russet Burbank was used as a susceptible standard in 2001. Entries were planted in single rows with five to seven seed pieces at $23-\mathrm{cm}$ intervals per plot. Plots were $1.3 \mathrm{~m}$ long and planting depth was $10 \mathrm{~cm}$. Plots within a row were separated by $1.6 \mathrm{~m}$. Width between rows was $96.5 \mathrm{~cm}$. Plots on adjacent rows were staggered to facilitate plant growth and disease assessment. Entries were arranged in a randomized complete block design with three replicates. The entire plot area was bordered on two sides with two rows of cv. White Rose, which is susceptible to $P$. infestans.

Plots were fertilized with a preplant broadcast application of $37 \mathrm{~kg}$ of N, $74 \mathrm{~kg}$ of $\mathrm{KCl}, 11 \mathrm{~kg}$ of $\mathrm{MnSO}_{4}, 2 \mathrm{~kg}$ of $\mathrm{ZnSO}_{4}$, and $6 \mathrm{~kg}$ of $\mathrm{B}$ per 0.4 ha. A banded application of 10-34-0 (615 liters/ha) also was applied at planting. Metribuzin (Sencor 75 DF; Bayer Cropscience, Research Triangle
Park, NC) was used for pre-emergence weed control at $335 \mathrm{~g}$ a.i./ha, and was applied 3 days post planting. Fungicides were not applied to foliage.

Potato foliage in both years was infected by naturally occurring inoculum. Severity of late blight symptoms was assessed on 17 August 2000 and 7 September 2001. These dates were selected because 80 to $100 \%$ of the foliage of the susceptible controls had late blight symptoms. The surface area of leaves, stems, and flowers with late blight symptoms was estimated visually in each plot as percentage of infected tissue (17). The total surface area then was partitioned into the percentage of leaf, stem, and flower tissue that had symptoms. The pedicle and peduncle were considered to be part of the flower tissue. In 2000 , the number of infected flowers and total number of flowers in plots of each clone were counted. In general, the leaf, stem, and flower tissue accounted for approximately 70,26 , and $4 \%$, respectively, of the total plant tissue.

Total rainfall from 2 June to 22 September 2000 and from 22 May to 19 September 2001 was 13.6 and $17.6 \mathrm{~cm}$, respectively, and the maximum and minimum temperatures were 21.4 and $10.7^{\circ} \mathrm{C}$ in 2000 and 21.0 and $10.3^{\circ} \mathrm{C}$ in 2001 , respectively. Drip irrigation provided additional water in the amounts of $25.4 \mathrm{~cm}$ in 2000 and $28.4 \mathrm{~cm}$ in 2001. Plots were harvested on 22 September in 2000 and 19 September in 2001, and the total weight of tubers per plot was determined. Tubers with late blight symptoms were detected visually and weighed.

Infected leaflet, stem, tuber, or fruit lesions from 12 plants were taken from the field plots on 13 September 2000 and 28 August 2001 to obtain isolates of $P$. infestans. One to three isolates were obtained from discreet lesions of samples using techniques previously described (6), except that sterile, moistened filter paper strips approximately 3 by $15 \mathrm{~mm}$ in size were used to transfer sporangia from sporulating lesions to rye agar medium. Clonal lineage of isolates was determined using methods for allozyme analysis described by Goodwin (10).

Classification of resistant responses. Leaflets, stems, flowers, and tubers were categorized as being highly resistant, moderately resistant, or susceptible in field, greenhouse, and laboratory experiments based on tissue responses to infection and lesion size (Table 1). Leaflets in greenhouse experiments with AULEC values of 0 to 200 were considered highly resistant. These leaflets either had black flecking with no additional lesion formation or small lesions between 0 to $5 \mathrm{~mm}$ in diameter that did not continue to expand. Leaflets with AULEC values of 201 to 2299 were considered moderately resistant. These lesions continued to expand slowly and eventually covered the leaflet. Leaflets with AULEC values greater than 2300 were susceptible because lesions expanded rapidly. Resistance to infection and lesion expansion in stems and flowers in greenhouse experiments were categorized similarly (Table 1). Categorization of foliar resistance in field trials was based on percentage of blighted tissue.

Tubers in laboratory experiments with $2 \%$ or less external rot were considered highly resistant because visible symptoms of infection did not expand beyond the inoculated eye. Tubers of clones with 3 to $6 \%$ external tuber rot were moderately resistant because, even though they had a slower rate of lesion expansion, the lesion was still expanding and had the potential to eventually rot the entire tuber. Tubers of clones with $7 \%$ or greater external tuber rot were susceptible because lesions spread rapidly throughout the tuber. Tuber resistance in the field is difficult to discern because absence of infection may be due to escape (5), but clones with a percentage of infected tubers by weight of less than $0.1,0.11$ to 0.4 , and greater than 0.4 were considered to be resistant, moderately resistant, and susceptible, respectively (Table 1).

Data analysis. Field data for severity of late blight on leaflets, stems, and flowers and total severity were analyzed using analysis of variance (ANOVA), PROC GLM procedure of SAS (SAS Institute Inc., Cary, NC). Field data for the percentage of infected tubers by weight were transformed before analysis of variance using a PROC Rank procedure in SAS. Data in the greenhouse or laboratory for

Table 1. Values for mean area under the lesion expansion curve (AULEC) and disease severity classifications of leaflets, stems, flowers, and tubers of potato clones to Phytophthora infestans in laboratory and field trials

\begin{tabular}{|c|c|c|c|c|c|c|}
\hline \multirow[b]{3}{*}{ Plant part $^{\mathrm{z}}$} & \multicolumn{6}{|c|}{ AULEC ${ }^{\mathbf{y}}$} \\
\hline & \multicolumn{3}{|c|}{ Greenhouse or laboratory trials } & \multicolumn{3}{|c|}{ Field trials } \\
\hline & HR & MR & $\mathbf{S}$ & HR & MR & $\mathbf{S}$ \\
\hline Leaflet & $\leq 200$ & $201-2299$ & $\geq 2300$ & $\leq 5$ & $5.1-30$ & $\geq 30$ \\
\hline Stem & $\leq 150$ & 151-199 & $\geq 200$ & $0-2$ & $2.1-10$ & $\geq 10$ \\
\hline Flower & $\leq 210$ & 211-999 & $\geq 1000$ & 0 & $0.01-0.3$ & $\geq 0.4$ \\
\hline Tuber & $\leq 2$ & 3-6 & $7-100$ & $0-0.1$ & $0.11-0.4$ & $\geq 0.4$ \\
\hline
\end{tabular}

${ }^{\mathrm{y}} \mathrm{HR}=$ highly resistant, no lesion expansion; $\mathrm{MR}=$ moderately resistant, lesion expansion highly restricted but expanding slowly; $\mathrm{S}=$ susceptible, lesion expansion.

${ }^{\mathrm{z}}$ Leaflet, stem, and flower values are the mean AULEC in greenhouse trials and percentage of blighted tissue for field trials. Tuber values are the mean percentage of external blighted tissue in laboratory trials and percentage of infected tubers by weight in field trials. 
sporangia production on leaflets; AULEC on leaflets, stems, and flowers; and percentage of external tuber rot were analyzed using ANOVA, PROC GLM. Pairwise comparisons between clones for laboratory or greenhouse and field data were made using Fisher's least significant difference test $(P=0.05)$.

\section{RESULTS}

Greenhouse foliage and flower experiments. Mean AULEC values on inoculated leaflets in the greenhouse were either numerically or significantly higher for Russet Norkotah and lower for A90586-11 than all other entries in 1999 and 2000 (Table 2). Mean AULEC values on stems also were either numerically or significantly lower on A90586-11 for both years tested than all other cultivars $(P<0.05$; Table 2$)$. Quantity of sporangia produced was significantly greater $(P<0.05)$ on Gem Russet leaflets than all other cultivars and clones, except for Russet Burbank and Umatilla Russet in both trials and Russet Norkotah in the first trial (Table 2). Sporangia were not produced on leaflets of A90586-11 (Table 2). Generally, mean AULEC values were greater but sporangia production was reduced on leaflets located lower on the stem than on leaflets located higher on the stem (Table 3).

Leaflets and stems of 29 advanced clones varied in susceptibility to $P$. infestans when inoculated with isolates 1799 (US-8) and 110B (US-11) in 2000. The number of clones with leaflets classified as highly resistant, moderately resistant, and susceptible to lesion expansion was 13, 12, and 4 , respectively, when inoculated with isolate 1799 (US-8), and 11, 9, and 9, respectively, when inoculated with isolate 110B (US-11) (Table 4). The number of clones with stems classified as highly resistant, moderately resistant, and susceptible to lesion expansion was 14,4 , and 11 , respectively, when inoculated with isolate 1799 , and 20,2, and 7, respectively, when inoculated with isolate 110B (Table 4). The number of clones with leaflets or stems highly resistant to both the US-8 and US-11 isolates was 7 and 13, respectively.

Leaflets and stems of 10 advanced clones varied in susceptibility to $P$. infestans when inoculated with isolates 701 (US-8) and 110B (US-11) in 2001. The number of clones with leaflets classified as highly resistant, moderately resistant, and susceptible to lesion expansion was 2, 4, and 4 , respectively, when inoculated with isolate 701 (US-8), and 2, 5, and 3, respectively, when inoculated with isolate 110B (Table 4). The number of clones with stems classified as highly resistant, moderately resistant, and susceptible to lesion expansion was 9,1 , and 0 for both isolates 701 and $110 \mathrm{~B}$ (Table 4).

In 2001, the number of clones with flowers classified as resistant, moderately resistant, and susceptible to lesion expansion was 1,2 , and 7 , respectively, when inoculated with isolate 701, and, 2, 1, and 7 , respectively, when inoculated with isolate 110B (Table 4). The number of clones with leaflets, stems, and flowers resistant to both the US- 8 and US-11 isolate was 1, 8 , and 1 , respectively.

Laboratory tuber experiments. External tuber rot was significantly greater $(P<$ 0.05 ) for Ranger Russet than for Russet Legend, Gem Russet, Umatilla Russet, and A90586-11 in four of five trials conducted in the laboratory in 1998 and 1999 (Table 5). External tuber rot was $>7 \%$ for Bannock Russet and Russet Norkotah in all

Table 3. Mean area under the lesion expansion curve (AULEC) for leaflets at five canopy levels and mean number of sporangia produced per $113 \mathrm{~mm}^{2}$ at three canopy levels on nine commercial potato cultivars when leaflets were inoculated with Phytophthora infestans

\begin{tabular}{lcc}
\hline & \multicolumn{2}{c}{ AULEC $^{\mathbf{y}}$} \\
\cline { 2 - 3 } Parameter measured, canopy level $^{\mathbf{z}}$ & Trial 1 & Trial 2 \\
\hline Lesion expansion & & \\
Top & $4,309 \mathrm{ab}$ & $8,469 \mathrm{ab}$ \\
Top-middle & $6,081 \mathrm{ab}$ & $9,239 \mathrm{a}$ \\
Middle & $6,314 \mathrm{ab}$ & $9,920 \mathrm{ab}$ \\
Bottom-middle & $7,936 \mathrm{bc}$ & $10,165 \mathrm{ab}$ \\
Bottom & $8,671 \mathrm{c}$ & $12,298 \mathrm{c}$ \\
LSD $(P=0.05)$ & 2,102 & 2,887 \\
Sporangia production & & \\
Top & $18,052 \mathrm{a}$ & $8,466 \mathrm{a}$ \\
Middle & $11,474 \mathrm{~b}$ & $5,658 \mathrm{ab}$ \\
Bottom & $11,639 \mathrm{~b}$ & $5,000 \mathrm{~b}$ \\
LSD $(P=0.05)$ & 3,669 & 3,120 \\
\hline
\end{tabular}

y Values followed by the same letter are not significantly different at $P=0.05$ according to Fisher's least significant difference (LSD).

${ }^{\mathrm{z}}$ Leaflets were inoculated with 10,000 sporangia/ml of water with a US- 8 isolate. All clones demonstrated the same trend of increasing mean AULEC moving from the top to the bottom of the plant canopy; therefore, mean AULECs were combined for all clones at each of the five canopy levels. All clones demonstrated the same trend of decreasing number of sporangia produced moving from the top to the bottom of the plant canopy; therefore, mean numbers of sporangia were combined for all clones at each of the three canopy levels.

Table 2. Mean area under the lesion expansion curve (AULEC) of leaflets and stems, mean number of sporangia produced on infected leaflets, and severity values of potato foliage in the field of nine potato clones when either stems and leaflets were inoculated with spores of Phytophthora infestans under greenhouse conditions in Pullman, WA, or when foliage was infected by naturally occurring inoculum in the field at Mount Vernon, WA

\begin{tabular}{|c|c|c|c|c|c|c|c|}
\hline \multirow[b]{3}{*}{ Cultivar } & \multicolumn{6}{|c|}{ Foliage greenhouse (AULEC)w } & \multirow{3}{*}{$\frac{\text { Field severity }^{z}}{2000}$} \\
\hline & \multicolumn{2}{|c|}{ Leaflet $^{x}$} & \multicolumn{2}{|c|}{ Stem $^{y}$} & \multicolumn{2}{|c|}{ Sporangia production } & \\
\hline & 1999 & 2000 & 1999 & 2000 & Trial 1 & Trial 2 & \\
\hline Ranger Russet & $6,832 \mathrm{~b}$ & $4,996 \mathrm{c}$ & $7,605 \mathrm{abc}$ & 649 bcde & $4,513 \mathrm{~cd}$ & $11,385 \mathrm{~b}$ & $99 \mathrm{a}$ \\
\hline Russet Burbank & $8,031 \mathrm{ab}$ & $\ldots$ & $9,041 \mathrm{a}$ & $\ldots$ & $16,132 \mathrm{a}$ & $14,432 \mathrm{ab}$ & $98 \mathrm{a}$ \\
\hline Russet Norkotah & $9,823 \mathrm{a}$ & $9,651 \mathrm{a}$ & $7,977 \mathrm{ab}$ & $1,185 \mathrm{ab}$ & $9,585 \mathrm{bc}$ & $12,833 \mathrm{~b}$ & $100 \mathrm{a}$ \\
\hline Bannock Russet & $8,110 \mathrm{ab}$ & $2,536 \mathrm{ed}$ & 7,013 abcd & 603 cde & $3,227 \mathrm{~d}$ & $12,771 \mathrm{~b}$ & $97 \mathrm{a}$ \\
\hline Russet Legend & $6,306 \mathrm{~b}$ & $4,085 \mathrm{~cd}$ & 4,064 bcde & $469 \mathrm{de}$ & $2,916 \mathrm{~d}$ & $12,534 \mathrm{~b}$ & $93 a$ \\
\hline Umatilla Russet & $5,964 \mathrm{~b}$ & $4,773 \mathrm{c}$ & $2,871 \mathrm{cde}$ & 995 bcd & $9,109 \mathrm{bc}$ & $15,580 \mathrm{ab}$ & $96 a$ \\
\hline Gem Russet & $6,858 \mathrm{~b}$ & $9,106 \mathrm{ab}$ & $2,618 \mathrm{de}$ & $1,711 \mathrm{a}$ & $11,132 \mathrm{ab}$ & $20,000 \mathrm{a}$ & $95 \mathrm{a}$ \\
\hline Shepody & $\ldots$ & $7,656 \mathrm{~b}$ & $\ldots$ & $1,114 \mathrm{cb}$ & $\ldots$ & $\ldots$ & $98 \mathrm{a}$ \\
\hline A90586-11 & $104 \mathrm{c}$ & $1,022 \mathrm{e}$ & $30 \mathrm{e}$ & $122 \mathrm{e}$ & $0 \mathrm{~d}$ & $0 \mathrm{c}$ & $32 \mathrm{~b}$ \\
\hline $\operatorname{LSD}(P=0.05)$ & 2,820 & 1,610 & 4,904 & 543 & 5,529 & 6,024 & 8 \\
\hline
\end{tabular}

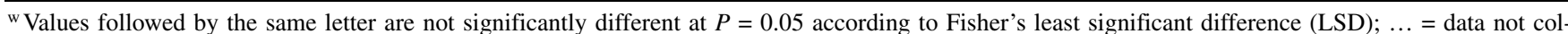
lected.

${ }^{x}$ Five leaflets were inoculated on each plant. Inoculated leaflets ranged from the top to the bottom of the stem. Leaflets were inoculated on the right proximal leaflet to the terminal leaflet facing out from the stem.

y Stems were inoculated at the midpoint of their length on the smooth surface midway between two internodes.

${ }^{\mathrm{z}}$ Percentage of tissue in plot with late blight symptoms. 
trials (Table 5). External tuber rot was $<7 \%$ for Russet Legend, Umatilla Russet, and A90586-11 in all trials (Table 5).

In 2000, the percentage of external tuber rot ranged from 0 to $84 \%$ in the third ex- periment when tubers of 29 advanced clones and three cultivars (Russet Norkotah, Ranger Russet, and Russet Burbank) were evaluated for resistance to isolates 1799 and 110B of P. infestans (Table 4).
External tuber rot was $20 \%$ for the US-8 isolate and $15 \%$ for the US-11 across all clones and cultivars $(P<0.05)$. The number of clones classified as highly resistant, moderately resistant, and susceptible to

Table 4. Mean area under the lesion expansion curve (AULEC) for leaflets, stems, and flowers and percentage of external rot of tubers when tissues were inoculated with US-8 and US-11 clonal lineages of Phytophthora infestans under greenhouse and laboratory conditions in Pullman, WA in 2000 and $2001^{x}$

\begin{tabular}{|c|c|c|c|c|c|c|c|c|c|c|c|c|c|c|c|}
\hline \multirow[b]{3}{*}{ Clone } & \multicolumn{10}{|c|}{ Foliage in greenhouse (AULEC) ${ }^{y}$} & \multicolumn{5}{|c|}{ External tuber rot in laboratory $(\%)^{z}$} \\
\hline & \multicolumn{2}{|c|}{ Leaflets 2000} & \multicolumn{2}{|c|}{ Stem 2000} & \multicolumn{2}{|c|}{ Leaflets 2001} & \multicolumn{2}{|c|}{ Stem 2001} & \multicolumn{2}{|c|}{ Flower 2001} & \multicolumn{2}{|c|}{2000} & \multicolumn{3}{|c|}{2001} \\
\hline & $\begin{array}{c}\text { US-8 } \\
\text { (1799) }\end{array}$ & $\begin{array}{c}\text { US-11 } \\
(110 B)\end{array}$ & $\begin{array}{c}\text { US-8 } \\
\text { (1799) }\end{array}$ & $\begin{array}{c}\text { US-11 } \\
(110 B)\end{array}$ & $\begin{array}{l}\text { US-8 } \\
\text { (701) }\end{array}$ & $\begin{array}{l}\text { US-11 } \\
\text { (110B) }\end{array}$ & $\begin{array}{l}\text { US-8 } \\
\text { (701) }\end{array}$ & $\begin{array}{l}\text { US-11 } \\
\text { (110B) }\end{array}$ & $\begin{array}{l}\text { US-8 } \\
\text { (701) }\end{array}$ & $\begin{array}{l}\text { US-11 } \\
\text { (110B) }\end{array}$ & $\begin{array}{c}\text { US-8 } \\
\text { (1799) }\end{array}$ & $\begin{array}{c}\text { US-11 } \\
\text { (110B) }\end{array}$ & $\begin{array}{c}\text { US-8 } \\
\text { (1799) }\end{array}$ & $\begin{array}{l}\text { US-8 } \\
\text { (701) }\end{array}$ & $\begin{array}{c}\text { US-11 } \\
\text { (110B) }\end{array}$ \\
\hline Russet Norkotah & 9,678 & 17,559 & 2,156 & 1,430 & & & & & & & 51 & 28 & 85 & 31 & 35 \\
\hline Ranger Russet & 4,933 & 9,968 & 2,774 & 2,495 & 8,148 & 7,125 & 1,967 & 2,218 & 6,775 & 5,972 & 84 & 66 & 58 & 38 & 63 \\
\hline Russet Burbank & & & & & 14,240 & 8,426 & 3,933 & 1,899 & 948 & 645 & 27 & 35 & 4 & 33 & 49 \\
\hline A9549-91 & 3,220 & 8,726 & 827 & 518 & $\ldots$ & $\ldots$ & $\ldots$ & $\ldots$ & $\ldots$ & $\ldots$ & 21 & 18 & 19 & 18 & 20 \\
\hline AWN85540-1 & 2,537 & 91 & 416 & 200 & $\ldots$ & $\ldots$ & $\ldots$ & $\ldots$ & $\ldots$ & $\ldots$ & 1 & 0 & 12 & 0.1 & 26 \\
\hline AWN86524-5 & 2,340 & 5,871 & 2,297 & 384 & $\ldots$ & $\ldots$ & $\ldots$ & $\ldots$ & $\ldots$ & $\ldots$ & 1 & 1 & 1 & 0.02 & 1 \\
\hline A9511-31 & 2,302 & 8,310 & 8 & 8 & $\ldots$ & & $\ldots$ & $\ldots$ & $\ldots$ & $\ldots$ & 56 & 74 & & & \\
\hline A90586-11 & 1,997 & 61 & 778 & 44 & 54 & 488 & 8 & 0 & 204 & 0 & 1 & 0.25 & 7 & 0.03 & 2 \\
\hline A9540-84 & 1,744 & 4,824 & 180 & 153 & 2,536 & 2,572 & 0 & 132 & 4,660 & 2,742 & 9 & 14 & 12 & 9 & 33 \\
\hline A9538-27 & 1,322 & 2,617 & 171 & 108 & 4,387 & 2,580 & 169 & 106 & 6,404 & 6,210 & 5 & 13 & 7 & 0.3 & 5 \\
\hline A9583-1 & 1,294 & 2 & 34 & 3 & $\ldots$ & $\ldots$ & $\ldots$ & $\ldots$ & $\ldots$ & $\ldots$ & 7 & 0 & 1 & 0.1 & 1 \\
\hline A9538-1 & 1,254 & 10,275 & 308 & 46 & $\ldots$ & $\ldots$ & $\ldots$ & $\ldots$ & $\ldots$ & $\ldots$ & 13 & 7 & $\ldots$ & $\ldots$ & $\ldots$ \\
\hline A9538-59 & 1,097 & 8,470 & 233 & 895 & $\ldots$ & $\ldots$ & $\ldots$ & $\ldots$ & $\ldots$ & $\ldots$ & 12 & 13 & $\ldots$ & $\ldots$ & $\ldots$ \\
\hline A9538-14 & 814 & 3,889 & 239 & 283 & 7,789 & 4,971 & 48 & 27 & 1,688 & 1,322 & 36 & 26 & 9 & 2 & 12 \\
\hline A9521-62 & 485 & 2913 & 6 & 93 & $\ldots$ & $\ldots$ & $\ldots$ & $\ldots$ & & ser & 76 & 50 & $\ldots$ & 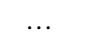 & \\
\hline A9512-3 & 459 & 104 & 176 & 6 & 1,990 & 660 & 10 & 40 & 5,540 & 589 & 28 & 18 & 26 & 23 & 20 \\
\hline A9514-8 & 459 & 1,414 & 59 & 8 & $\ldots$ & $\ldots$ & $\ldots$ & $\ldots$ & $\ldots$ & $\ldots$ & 1 & 1 & $\ldots$ & $\ldots$ & $\ldots$ \\
\hline J138-A4 & 340 & 1,608 & 1,810 & 963 & $\ldots$ & $\ldots$ & $\ldots$ & $\ldots$ & $\ldots$ & $\ldots$ & 26 & 23 & 14 & 9 & 8 \\
\hline J103-K7 & 244 & 405 & 161 & 102 & $\ldots$ & $\ldots$ & $\ldots$ & $\ldots$ & $\ldots$ & $\ldots$ & 34 & 19 & 61 & 17 & 93 \\
\hline A9513-32 & 173 & 466 & 455 & 203 & $\ldots$ & $\ldots$ & $\ldots$ & $\ldots$ & $\ldots$ & $\ldots$ & 33 & 19 & $\ldots$ & & $\ldots$ \\
\hline J138-A12 & 167 & 166 & 131 & 147 & $\ldots$ & - & $\ldots$ & $\ldots$ & $\ldots$ & $\ldots$ & 0.25 & 0.25 & 33 & 19 & 35 \\
\hline A9583-56 & 153 & 26 & 250 & 2 & 2,142 & 490 & 119 & 191 & 4,698 & 3,854 & 1 & 1 & 3 & 0.2 & 2 \\
\hline A9520-18 & 136 & 107 & 8 & 8 & $\ldots$ & $\ldots$ & $\ldots$ & $\ldots$ & $\ldots$ & $\ldots$ & 5 & 18 & $\ldots$ & $\ldots$ & $\ldots$ \\
\hline A9553-68 & 111 & 460 & 150 & 229 & 2,280 & 1,463 & 29 & 16 & 3,199 & 1,510 & 1 & 1 & 1 & 0.1 & 1 \\
\hline B0718-3 & 109 & 1,074 & 13 & 22 & $\ldots$ & $\ldots$ & $\ldots$ & $\ldots$ & $\ldots$ & $\ldots$ & 63 & 16 & 1 & 1 & 1 \\
\hline A9510-59 & 97 & 1,077 & 62 & 68 & $\ldots$ & $\ldots$ & $\ldots$ & $\ldots$ & $\ldots$ & $\ldots$ & 40 & 19 & $\ldots$ & $\ldots$ & $\ldots$ \\
\hline A9588-18 & 70 & 15 & 112 & 8 & $\ldots$ & $\ldots$ & $\ldots$ & $\ldots$ & $\ldots$ & $\ldots$ & 1 & 2 & 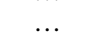 & $\ldots$ & $\ldots$ \\
\hline A95020-17 & 69 & 188 & 5 & 7 & 1,697 & 167 & 1 & 1 & 648 & 1,292 & 0 & 6 & 45 & 2 & 24 \\
\hline PI583331 & 52 & 303 & 31 & 8 & $\ldots$ & $\ldots$ & $\ldots$ & $\ldots$ & $\ldots$ & & 0 & 0 & 0 & 0 & 0 \\
\hline A95053-61 & 39 & 301 & 28 & 10 & 3,249 & 313 & 25 & 14 & 1,893 & 2,740 & 1 & 1 & 0.2 & 0.02 & 1 \\
\hline A9506-1 & 15 & 26 & 263 & 28 & $\ldots$ & $\ldots$ & $\ldots$ & $\ldots$ & $\ldots$ & $\ldots$ & 15 & 2 & $\ldots$ & $\ldots$ & $\ldots$ \\
\hline A95020-70 & 12 & 26 & 6 & 20 & 8 & 1 & 2 & 2 & 781 & 177 & 0.25 & 0 & 0.3 & 6 & 1 \\
\hline $\operatorname{LSD}(P=0.05)$ & 1,154 & 2,588 & 604 & 595 & 4,845 & 2,910 & 2,465 & 1,670 & 3,814 & 3,755 & 26 & 19 & 18 & 10 & 16 \\
\hline
\end{tabular}

${ }^{\mathrm{x}}$ Isolate identification number shown in parenthesis; ... indicates data not taken; LSD = least significant difference.

y Three to six leaflets were inoculated on each plant. Inoculated leaflets ranged from the top to the bottom of the stem. Leaflets were inoculated on the right or left proximal leaflet to the terminal leaflet facing out from the stem; stems were inoculated at the midpoint of their length on the smooth surface midway between two internodes; young flowers were inoculated on the stigma and lesion size on the pedicle measured.

${ }^{z}$ Tubers were inoculated on a single bud. Tubers were assessed for severity of late blight symptoms after 36 days. Tubers were peeled to a depth of $3 \mathrm{~mm}$ and the percentage of external rot determined.

Table 5. Mean percentage of external tuber rot and percentage of infected tubers for nine potato clones when tubers were inoculated with either US-8 or US-11 clonal lineages of Phytophthora infestans under laboratory conditions in Pullman, WA, in 1998 and 1999, or naturally infected in the field at Mount Vernon, WA in $2000^{\mathrm{y}}$

\begin{tabular}{|c|c|c|c|c|c|c|}
\hline \multirow[b]{4}{*}{ Clone } & \multicolumn{5}{|c|}{ External tuber rot $(\%)$} & \multirow{4}{*}{$\begin{array}{c}\text { Infected tubers }(\%)^{\mathbf{z}} \\
\text { Field } \\
2000 \\
\end{array}$} \\
\hline & \multicolumn{5}{|c|}{ Laboratory } & \\
\hline & 1998 & \multicolumn{2}{|c|}{1999 , trial 1} & \multicolumn{2}{|c|}{ 1999, trial 2} & \\
\hline & US-8 (1799) & US-8 (1799) & US-11 (110B) & US-8 (1799) & US-11 (110B) & \\
\hline Ranger Russet & $41.9 \mathrm{a}$ & $80.4 \mathrm{a}$ & $95.5 \mathrm{a}$ & $73.3 \mathrm{a}$ & $24.3 \mathrm{ab}$ & $4.4 \mathrm{a}$ \\
\hline Bannock Russet & $29.5 \mathrm{ab}$ & $12.1 \mathrm{~cd}$ & $8.8 \mathrm{c}$ & $24.6 \mathrm{~b}$ & $22.1 \mathrm{ab}$ & $4.6 \mathrm{a}$ \\
\hline Russet Norkotah & $17.8 \mathrm{cb}$ & $44.6 \mathrm{~b}$ & $30 \mathrm{~b}$ & $61.3 \mathrm{a}$ & $42.9 \mathrm{a}$ & $5.1 \mathrm{a}$ \\
\hline Russet Burbank & $8.4 \mathrm{cb}$ & $41.3 \mathrm{bc}$ & $0 \mathrm{c}$ & $17.9 \mathrm{~b}$ & $23.4 \mathrm{ab}$ & $0 \mathrm{~b}$ \\
\hline Russet Legend & $6.5 \mathrm{c}$ & $0 \mathrm{~d}$ & $0 \mathrm{c}$ & $0 \mathrm{~b}$ & $0.5 \mathrm{~b}$ & $0.4 \mathrm{ab}$ \\
\hline Gem Russet & $0.1 \mathrm{c}$ & $0 \mathrm{~d}$ & $16.7 \mathrm{bc}$ & $0 \mathrm{~b}$ & $0 \mathrm{~b}$ & $2.7 \mathrm{ab}$ \\
\hline Umatilla Russet & $0.1 \mathrm{c}$ & $0 \mathrm{~d}$ & $5.8 \mathrm{c}$ & $0 \mathrm{~b}$ & $0 \mathrm{~b}$ & $1.3 \mathrm{ab}$ \\
\hline A90586-11 & $0.1 \mathrm{c}$ & $0 \mathrm{~d}$ & $0 \mathrm{c}$ & $0 \mathrm{~b}$ & $0 \mathrm{~b}$ & $0.1 \mathrm{~b}$ \\
\hline $\operatorname{LSD}(P=0.05)$ & 21.8 & 30.3 & 17.3 & 27.7 & 37.7 & 4.0 \\
\hline
\end{tabular}

${ }^{y}$ Isolate identification number shown in parentheses. Values followed by the same letter are not significantly different at $P=0.05$ according to Fisher's least significant difference.

${ }^{\mathrm{z}}$ Percentage of infected tubers by weight. 
external tuber rot was 12,2 , and 15 , respectively, when inoculated with isolate 1799 , and 13,1 , and 15 , respectively, when inoculated with isolate 110B (Table 4).

In 2001, the percentage of external tuber rot ranged from 0 to $93 \%$ when tubers of 19 clones and three cultivars (Russet Norkotah, Ranger Russet, and Russet Burbank) were evaluated for resistance to isolates 1799,701 , and $110 \mathrm{~B}$ of $P$. infestans (Table 4). Mean percentage of external rot among isolates was not compared because the environmental conditions and dates of inoculation were not the same. The number of clones classified as highly resistant, moderately resistant, and susceptible to external rot was 7,1 , and 11 , respectively, when inoculated with isolate $1799 ; 12,1$, and 6 , respectively, when inoculated with isolate 701 ; and 9,1 , and 9 , respectively, when inoculated with isolate 110B (Table 4).

Field trials. Only the US- 8 clonal lineage of $P$. infestans was isolated from late blight lesions in the field in 2000 and 2001. Severity of late blight on foliage of the commercial cultivars and A90586-11 ranged from 32 to $100 \%$ in the field in 2000 (Table 2). Foliage of the commercial cultivars was highly susceptible (severity $\geq 93 \%$ ) to late blight in 2000 ; therefore, they were not all reevaluated in 2001. Percentage of infected tubers (by weight) was significantly higher $(P<0.05)$ for Ranger Russet, Bannock Russet, and Russet Norkotah than for Russet Burbank and A90586-11 in 2000 (Table 5).
The susceptible standards Russet Norkotah, Ranger Russet, and Russet Burbank had 100,99 , and $98 \%$ disease severity on total foliage, respectively, in 2000, and $84 \%$ on Russet Burbank in 2001 (Table 6). In contrast, total severity of late blight on advanced clones in the field ranged from 0.3 to $73 \%$ in 2000 and 2 to $54 \%$ in 2001 (Table 6). Severity of late blight on leaf tissue of advanced clones ranged from 0.2 to $47 \%$ in 2000 and 2 to $51 \%$ in 2001 (Table 6). Severity of late blight on stem tissue of advanced clones ranged from 0 to $24.7 \%$ in 2000 and 0 to $2.7 \%$ in 2001 . Severity of late blight on all flower parts of advanced clones ranged from 0 to $3 \%$ in 2000 and 0 to $1 \%$ in 2001 (Table 6). The percentage of infected flowers blossoms ranged from 0 to $83 \%$ in 2000 (Table 6). Percentage of infected tubers, by weight, of advanced clones ranged from 0 to $4.6 \%$ in 2000 and 0 to $3.9 \%$ in 2001 (Table 6).

\section{DISCUSSION}

Foliage of commercial potato cultivars in the Columbia Basin of the Pacific Northwest was highly susceptible to late blight infection and lesion expansion. Lesion expansion was greater on lower leaflets than on upper leaflets for all commercial cultivars when leaflets were inoculated on plants during early tuber bulking (Table 3 ). In the field, it also was noted that there was more infection on leaflets located in the lower canopy than for leaflets in the upper canopy, although the levels were not quantified. Higher susceptibility of lower leaflets than upper leaflets has been observed previously on other cultivars $(35,42)$. Thorough coverage of fungicides in commercial fields would be especially important on the lower leaflets which were more susceptible to lesion expansion in the this study.

Although lower leaflets were more susceptible to lesion expansion, more sporangia were produced on infected leaflets in the upper canopy than on infected leaflets in the lower canopy on the commercial cultivars tested in the greenhouse (Table 3 ). Older and younger leaflets differ in protein and nitrogen levels $(27,44)$. Younger leaflets may provide a better substrate for sporulation of obligate parasites, such as $P$. infestans, than senescing leaf tissue. Producing a greater number of sporangia on leaflets at the top of the canopy also would benefit the dispersal of spores of $P$. infestans.

Screening of advanced clones in the greenhouse for resistance to $P$. infestans was more stringent than natural infections in the field in 2000 and 2001. High levels of foliar resistance were observed for clones A9512-3, J138-A12, A9553-68, PI583331, A95053-61, and A95020-70 in the field (Table 6); however, in the greenhouse, only clones J138-A12 and A9502070 had high levels of foliar resistance, and clones PI583331 and A9512-3 had high-tomoderate levels of foliar resistance (Table 4). Foliage in the greenhouse was tested with both US-8 and US-11 clonal lineages, but in the field only the US- 8 clonal line-

Table 6. Severity of late blight on leaves, stems, and flowers; percentage of infected flower blossoms; and percentage of infected tubers by weight on potato tissue naturally infected with Phytophthora infestans in the field in Mount Vernon, WA, in 2000 and $2001^{\mathrm{w}}$

\begin{tabular}{|c|c|c|c|c|c|c|c|c|c|c|c|}
\hline \multirow[b]{3}{*}{ Clone } & \multicolumn{8}{|c|}{ Severity } & \multicolumn{3}{|c|}{ Infected (\%) } \\
\hline & \multicolumn{2}{|c|}{ Leaf } & \multicolumn{2}{|c|}{ Stem } & \multicolumn{2}{|c|}{ Flower $^{x}$} & \multicolumn{2}{|c|}{ Total $^{y}$} & \multirow{2}{*}{$\frac{\text { Blossoms }^{\mathrm{z}}}{2000}$} & \multicolumn{2}{|c|}{ Tubers } \\
\hline & 2000 & 2001 & 2000 & 2001 & 2000 & 2001 & 2000 & 2001 & & 2000 & 2001 \\
\hline Russet Norkotah & 70 & $\ldots$ & 26 & $\ldots$ & 4 & $\ldots$ & 100 & $\ldots$ & $\ldots$ & 5.1 & $\ldots$ \\
\hline Ranger Russet & 70 & $\ldots$ & 25 & $\ldots$ & 4 & $\ldots$ & 99 & $\ldots$ & $\ldots$ & 4.4 & $\ldots$ \\
\hline Russet Burbank & 70 & 70 & 24 & 10.3 & 4 & 3.7 & 98 & 84 & 61 & 0 & 0 \\
\hline A95549-91 & 21 & $\ldots$ & 2.3 & $\ldots$ & 1.7 & $\ldots$ & 25 & $\ldots$ & 53 & 0.1 & $\ldots$ \\
\hline AWN85540-1 & 47 & $\ldots$ & 24.7 & $\ldots$ & 2.3 & $\ldots$ & 73 & $\ldots$ & 83 & 4.6 & $\ldots$ \\
\hline AWN86524-5 & 23 & $\ldots$ & 8 & $\ldots$ & 1 & $\ldots$ & 35 & $\ldots$ & 28 & 0.5 & $\ldots$ \\
\hline A90586-11 & 30 & 46 & 1.3 & 0.4 & 0.1 & 0.4 & 32 & 47 & 18 & 0.1 & 0.2 \\
\hline A9540-84 & 20 & 51 & 8.3 & 2.7 & 3 & 1 & 32 & 54 & 64 & 0 & 1.4 \\
\hline A9538-27 & 20 & 41 & 0.07 & 0.1 & 0.4 & 0.4 & 20 & 42 & 35 & 0 & 1.3 \\
\hline A9583-1 & 12 & $\ldots$ & 0.7 & $\ldots$ & 0.4 & $\ldots$ & 13 & $\ldots$ & 20 & 0.5 & $\ldots$ \\
\hline A9538-14 & 29 & $\ldots$ & 1 & $\ldots$ & 0.1 & $\ldots$ & 30 & $\ldots$ & 22 & 0 & $\ldots$ \\
\hline A9512-3 & 0.2 & 5 & 0 & 0.03 & 0.2 & 0.1 & 0.4 & 5 & 37 & 0 & 0.5 \\
\hline J138-A4 & 13 & $\ldots$ & 0.07 & $\ldots$ & 0.7 & $\ldots$ & 13 & $\ldots$ & 39 & 0 & $\ldots$ \\
\hline $\mathrm{J} 103-\mathrm{K} 7$ & 9 & 31 & 0.03 & 0.1 & 2 & 1 & 11 & 32 & 51 & 0.5 & 1.1 \\
\hline $\mathrm{J} 138-\mathrm{A} 12$ & 1 & $\ldots$ & 0.07 & $\ldots$ & 1.1 & $\ldots$ & 2 & $\ldots$ & 79 & 0.3 & $\ldots$ \\
\hline A9583-56 & 3 & 30 & 0.1 & 0.07 & 1 & 0.4 & 4 & 30 & 57 & 0 & 0.1 \\
\hline A9553-68 & 0.8 & 3 & 0.03 & 0.07 & 1 & 0.4 & 1.8 & 4 & 52 & 0 & 2.1 \\
\hline B0718-3 & 25 & 15 & 1.3 & 0.1 & 0.1 & 0.1 & 27 & 15 & 32 & 0.3 & 3.3 \\
\hline A95020-17 & 0.5 & 13 & 0 & 0 & 0 & 0 & 0.5 & 13 & 0 & 0.1 & 0.9 \\
\hline PI583331 & 0.7 & 4 & 0.03 & 0.07 & 0.07 & 0.4 & 0.8 & 4 & 3 & 0.6 & 3.9 \\
\hline A95053-61 & 0.3 & 3 & 0 & 0 & 0.2 & 0.1 & 0.5 & 4 & 17 & 0.3 & 0 \\
\hline A95020-70 & 0.2 & 2 & 0 & 0 & 0.1 & 0.1 & 0.3 & 2 & 12 & 0 & 0 \\
\hline $\operatorname{LSD}(P=0.05)$ & 8.6 & 16.4 & 9.2 & 8.0 & 1.5 & 1.3 & 7.6 & 2.4 & 22 & 4.2 & 6.9 \\
\hline
\end{tabular}

\footnotetext{
${ }^{\mathrm{w}}$ Russet Norkotah, Ranger Russet, and Russet Burbank served as susceptible standards; ... indicates data not taken; LSD = least significant difference.

${ }^{x}$ Flower tissue includes blossom, pedicle, and peduncle with late blight symptoms.

y Percentage of the total tissue with late blight symptoms (leaf + stem + flower severities).

$\mathrm{z}$ The mean number of blossoms observed per clone was 135 with a range from 27 to 259 .
} 
age was detected and may account for the differences. Although complex virulences of both US- 8 and US-11 isolates have been identified in populations of $P$. infestans in western Washington in previous years (4), both lineages were not detected in 2000 and 2001.

Depending on the clonal lineage of $P$. infestans used to inoculate the tissue in the greenhouse, high levels of foliar resistance were detected among clones. Clones B0718-3, A9510-59, and PI58331 were highly resistant to the US-8 clonal lineage. Clones AWN85540-1, A9583-1, A9506-1, and A95020-17 were highly resistant to the US-11 clonal lineage. Only clones J138A12, A9588-18, A9520-18, and A9502070 were highly resistant to both of these clonal lineages of $P$. infestans. Thus, greenhouse screening of resistance of clones to $P$. infestans using various clonal lineages of $P$. infestans is advantageous, especially in areas where only a single clonal lineage may exist.

Relative susceptibility of flowers to $P$. infestans among cultivars and clones has not been previously reported. Potato flowers were highly susceptible to infection by $P$. infestans in the field and greenhouse, even for clones that had high levels of resistance in leaflets and stems. Complete resistance to flower infection was not observed for any clone in both the greenhouse and field. Flowers of A90586-11 were highly resistant to both the US- 8 and US-11 clonal lineages, and A95020-70 was highly resistant to the US-11 clonal lineage in the greenhouse (Table 4). Only A9502017 was highly resistant to infection in the field (Table 6). Potato flowers of clones in this study had a protruding style and stigma that were exposed even when the flower was closed. The stigma acts as a receptacle for pollen in the air but, at the same time, may receive sporangia of $P$. infestans. Based on field and greenhouse observations, the pollen tube in the pistil of a flower appeared to provide an entry point by which hyphae from germinating sporangia or zoospores on the surface of the stigma could infect.

Single flower lesions in the greenhouse were capable of expanding and killing entire plants. Flowers of potato clones varied in the length of the protruding style and length of pedicle proximal to the abscission ring. The abscission ring is the location of flower detachment from the remaining pedicle. The pedicle is divided by the abscission ring so that part of the pedicle remains on the plant and the other half falls to the ground with the flower (45). Style and pedicle length may be factors determining the expansion of lesions beyond the abscission ring before flower detachment, because of the distance hyphae must spread. Potato flowers in the present study generally detached from the plant 5 to 7 days after bloom. If the lesion expanded beyond the abscission ring be- fore flower detachment, the lesion continued to expand toward the peduncle and eventually into the stem. Many mature flowers detached before the expanding lesion moved beyond the abscission ring in preliminary flower inoculation tests (data not shown). Therefore, the stigma and style of young flowers were inoculated in this study so that the expanding lesion had sufficient time to expand beyond the abscission ring before flower detachment. This helped to eliminate lack of infection among the clones, possibly due to length of style and pedicle, and accounted for differences in duration of flower attachment and allowed for accurate assessment of flower resistance.

The presence of flowers in the field in 2000 coincided with a spore shower of natural inoculum of $P$. infestans. Even though high foliar resistance was exhibited by clones A9512-3, J138-A12, A9553-68, PI583331, A95053-61, and A95020-70 in the field in 2000 (Table 6), infections were observed on these clones, mostly on the pistils of the flowers. In contrast, leaf and stem tissue had no infection or few traces of infection. Weather conditions at the time of foliar assessment in the field were conducive for sporulation, and sporulation was observed on infected flowers of all clones except A95020-17 (Table 6). Breeding for flowerless clones would be beneficial for late blight resistance, as well as resistance to white mold (Sclerotinia sclerotiorum (Lib.) de Bary) (25).

High levels of resistance in tubers varied little among clones depending on the clonal lineage of $P$. infestans used to inoculate the eyes in the laboratory (Table 4). Clones AWN86524-5, A9514-8, A955368, A9588-18, PI583331, and A95053-61 all were highly resistant to the US- 8 and US-11 clonal lineages. The US- 8 isolates could have been used to determine resistance in tubers without testing tubers with the US-11 isolate or vice versa, even though this was not the case when determining high foliar resistance.

High levels of resistance to both tuber and leaflet infection varied among the clones in the laboratory and greenhouse experiments. Comparisons of resistance in tubers and leaflets were characterized as follows: clone A9588-18 had a high level of resistance in tubers and leaflets; clones A95020-70, PI583331, A9583-56, A955368, and A95053-61 had high or moderate levels of resistance in tubers and high or moderate levels of resistance in leaflets; clone AWN86524-5 had high levels of resistance in tubers but susceptible leaflets; clone A9510-59 had high to moderate resistance in leaflets but susceptible tubers; and clones A9506-1 and J138-A12 had high levels of resistance in leaflets and resistant to susceptible tubers (Table 4).

Several advanced clones with potential future use for the Pacific Northwest had high or moderate levels of resistance in foliage, flowers, and tubers to $P$. infestans US- 8 and US-11 clonal lineages in this study. Clones classified as highly resistant expressed quantitative differences compared with susceptible cultivars, and likely have a high level of partial resistance. Additional tests using a diversity of isolates of $P$. infestans are needed to more fully characterize resistance in the highly resistant clones. The black flecking on leaflets and stem tissue of some clones with high resistance indicated a hypersensitive response to the pathogen. Such reactions in potato to $P$. infestans can be due to partial resistance $(24,43)$.

\section{ACKNOWLEDGMENTS}

We thank L. M. Carris and R. E. Thornton for their critical review of this article, D. Corsini for providing the tuber material, and T. F. Cummings and Z. Kaanan-Atallah for technical assistance.

\section{LITERATURE CITED}

1. Black, W. 1970. The nature and inheritance of field resistance to late blight (Phytophthora infestans) in potatoes. Am. Potato J. 47:279-288.

2. Browning, J. A., Simons, M. D., and Torres, E. 1977. Managing host genes: epidemiologic and genetic concepts. Pages 191-212 in: Plant Pathology: An Advanced Treatise. Volume 1. J. G. Horsefall and E. B. Cowling, eds. Academic Press, New York.

3. Colon, L. T., Budding, D. J., Keizer, L. C. P., and Pieters, M. M. J. 1995. Components of resistance to late blight (Phytophthora infestans) in eight South American Solanum species. Eur. J. Plant Pathol. 101:441-456.

4. Derie, M. L., and Inglis, D. A. 2001. Persistence of complex virulences in populations of Phytophthora infestans in Western Washington. Phytopathology 91:606-612.

5. Dorrance, A. E., and Inglis, D. A. 1998. Assessment of laboratory methods for evaluating potato tubers for resistance to late blight. Plant Dis. 82:442-446.

6. Dorrance, A. E., Inglis, D. A., Derie, M. L. Brown, C. R., Goodwin, S. B., Fry, W. E., and Deahl, K. L. 1999. Characterization of Phytophthora infestans populations in western Washington. Plant Dis. 83:423-428.

7. Dorrance, A. E., Inglis, D. A., Helgeson, J. P., and Brown, C. R. 2001. Partial resistance to Phytophthora infestans in four Solanum crosses. Am. J. Potato Res. 78:9-17.

8. Flor, H. H. 1955. Host-parasite interaction in flax rust-its genetics and other implications. Phytopathology 45:680-685.

9. Fry, W. E., Thurston, H. D., and Stevenson, W. R. 2001. Late blight. Pages 28-30 in: Compendium of Potato Diseases, 2nd ed. W. R. Stevenson, R. Loria, G. D. Franc, and D. P. Weingartner, eds. American Phytopathological Society Press. St. Paul, MN.

10. Goodwin, S. B., Smart, C. D., Sandrock, R. W., Deahl, K. L., Punja, Z. K., and Fry, W. E. 1998. Genetic change within populations of Phytophthora infestans in the United States and Canada 1994 to 1996: role of migration and recombination. Phytopathology 88:939949.

11. Graham, K. M., and Hodgson, W. A. 1965. The effect of major and minor gene interaction on adaptive parasitism in Phytophthora infestans. Phytopathology 55:73-75.

12. Grunwald, N. J. Hinojosa, M. A. C., Covarrubias, O. R., Pena, A. R., Niederhauser, J. S., and Fry. W. E. 2002. Potato cultivars from the Mexican national program: sources and durability of resistance against late blight. Phytopathology 92:688-693.

13. Guzman-N, J. 1964. Nature of partial resis- 
tance of certain clones of three Solanum species to Phytophthora infestans. Phytopathology 54:1398-1404.

14. Hodgson, W. A. 1961. Laboratory testing of the potato for partial resistance to Phytophthora infestans. Am. Potato J. 38:259-264.

15. Inglis, D., Gundersen, B., Derie, M., and Corsini, D. 2000. Evaluation of potato germplasm for resistance to late blight, 2000. B\&C Tests 16:PT67.

16. Inglis, D. A., Johnson, D. A., Legard, D. E., Fry, W. E., and Hamm, P. B. 1996. Relative resistances of potato clones in response to new and old populations of Phytophthora infestans. Plant Dis. 80:575-578.

17. James, C. 1971. An illustrated series of assessment keys for plant disease, their preparation and usage. Can. Plant Dis. Surv. 52:3965 .

18. Jenkins, J. C., and Jones, R. K. 2003. Classifying the relative host reaction in potato cultivars and breeding lines to the US-8 strain of Phytophthora infestans in Minnesota. Plant Dis. 87:983-990.

19. Jensen, A. 2001. Potato varieties in the northwest. Potato Progr. Vol. 1, No. 10:1-4.

20. Johnson, D. A., Cummings, T. F., and Hamm, P. B. 2000. Cost of fungicides used to manage potato late blight in the Columbia Basin: 1996 to 1998. Plant Dis. 84:399-402.

21. Johnson, D. A., Cummings, T. F., Hamm, P. B., Rowe, R. C., Miller, J. S., Thornton, R. E., and Sorensen, E. J. 1997. Potato late blight in the Columbia Basin: an economic analysis of the 1995 epidemic. Plant Dis. 81:103-106.

22. Johnson, D. A., and Gilmore, E. C. 1979. Breeding for resistance to pathogens in wheat. Pages 263-275 in: Biology and Breeding for Resistance. M. K. Harris, ed. Texas A\&M University, College Station.

23. Johnson, R. 1984. A critical analysis of durable resistance. Annu. Rev. Phytopathol. 22:309330.

24. Kamoun, S., Hraber, P., Sobral, B., Nuss, D., and Grovers, F. 1999. Initial assessment of gene diversity for the oomycete pathogen Phytophthora infestans based on expressed se- quences. Fungal Genet. Biol. 28:94-106.

25. Kanaan-Atallah, Z.. and Johnson, D. A. 2004 Development of Sclerotinia stem rot in potato fields in south-central Washington. Plant Dis. 88:419-423.

26. Lapwood, D. H. 1961. Potato haulm resistance to Phytophthora infestans. Ann. Appl. Biol. 49:316-330.

27. Lowings, P. H., and Acha, I. G. 1959. Some factors affecting growth of Phytophthora infestans (Mont.) de Bary. Trans. Br. Mycol. Soc. 42:491-501.

28. Malcolmson, J. F. 1969. Factors involved in resistance to blight (Phytophthora infestans (Mont.) de Bary) in potatoes and assessment of resistance using detached leaves. Ann. Appl. Biol. 64:461-468.

29. Mastenbroek, C. 1966. Some major points from 22 years of experience in breeding potatoes for resistance to late blight (Phytophthora infestans). Am. Potato J. 43:261-277.

30. Parlevliet, J. E. 1979. Components of resistance that reduce the rate of epidemic development. Annu. Rev. Phytopathol. 17:203-222.

31. Porter, L. P., Johnson, D. J., and Cummings, T. F. 1999. Tuber resistance/susceptibility of new potato cultivars to late blight. Spud Topics $44: 2$.

32. Rowe, R. C. 1993. Potato health management: a holistic approach. Pages 3-10 in: Potato Health Management. R. C. Rowe, ed. American Phytopathological Society Press, St. Paul, $\mathrm{MN}$.

33. Shaner, G., and Finney, R. E. 1977. The effect of nitrogen fertilization on the expression of slow mildewing resistance in knox wheat. Phytopathology 67:1051-1056.

34. Stakman, E. C. 1968. What are the prospects for permanent control of cereal rusts? Pages 217-230 in: Proc. Cereal Rust Conf. Oeiras, Portugal.

35. Stewart, H. E. 1990. Effect of plant age and inoculum concentration on expression of major gene resistance to Phytophthora infestans in detached potato leaflets. Mycol. Res. 94:823826.

36. Swiezynski, K. M., Domanski, L., Sieczka, M.
T., and Zarzycka, H. 1993. Specific resistance to Phytophthora infestans in the potato. Genet. Pol. 34:327-336.

37. Swiezynski, K. M., Domanski, L., Sobkowiak, S., and Zarzycka, H. 1996. Reaction to Phy tophthora infestans of potato genotypes with race-specific resistance. Potato Res. 39:195203.

38. Thurston, H. D., Heidreick, L. E., and Guzman, J. 1962. Partial resistance to Phytophthora infestans (Mont.) de Bary within the coleccion central Colombiana. Am. Potato J. 39:63-69.

39. Tooley, P. W. 1990. Variation in resistance to Phytophthora infestans among 21 Solanum verrucosum plant productions. Am. Potato J. 67:491-498.

40. Trognitz, B. R. 1998. Inheritance of resistance in potato to lesion expansion and sporulation by Phytophthora infestans. Plant Pathol. 47:712-722.

41. Umaerus, V., Umaerus, M., Erjefält, and Nilsson, B. A. 1983. Control of Phytophthora by host resistance: problems and progress. Pages 315-326 in: Phytophthora: Its Biology, Taxonomy, Ecology and Pathology. D. C. Erwin, S. Bartnicki-Garcia, and P. H. Tsao, eds. American Phytopathological Society Press, St. Paul, MN.

42. Visker, M. H. P. W., Keizer, L. C. P., Budding, D. J., Van Loon, L. C., Colon, L. T., and Struik, P. C. 2003. Leaf position prevails over plant age and leaf age in reflecting resistance to late blight in potato. Phytopathology 93:666-674.

43. Vleeshouwers, V. G., van Dooijeweert, W., Govers, F., Kamoun, S., and Colon, L. T. 2000. The hypersensitive response is associated with host and nonhost resistance to Phytophthora infestans. Planta (Berlin) 210:853-864

44. Westermann, D. T. 1993. Fertility management. Pages 77-86 in: Potato Health Management. R. C. Rowe, ed. American Phytopathological Society Press, St. Paul, MN.

45. Whitehead, T., McIntosh, T. P., and Findlay, W. M. 1953. The Potato in Health and Disease. Third ed. Oliver and Boyd, London. 